\title{
Response of Sorghum Production in Kenya to Prices and Public Investments
}

\author{
Perez A. Onono ${ }^{1}$ \\ ${ }^{1}$ Department of Applied Economics, Kenyatta University, Nairobi, Kenya \\ Correspondence: Perez A. Onono, Department of Applied Economics, School of Economics, Kenyatta \\ University. P.O Box 43844 - 00100 Nairobi, Kenya. Tel: 254-722-295-389. E-mail: onono.perez@ ku.ac.ke
}

Received: December 4, 2017 Accepted: December 29, 2017 Online Published: January 30, 2018

doi:10.5539/sar.v7n2p19

URL: https://doi.org/10.5539/sar.v7n2p19

\begin{abstract}
Expansion of sorghum production in the arid and semi-arid areas in Kenya has been singled out as a potential for addressing food security challenges due to climate shocks affecting maize production and reduced availability of arable land in the medium and high potential areas. Towards achieving this the government has used guaranteed minimum output prices, input subsidies and public investments to promote agricultural developments as some of the instruments of policy to provide incentives to farmers. Literature is deficient of studies on production behaviour of sorghum in the country with respect to market prices and public investments. This study provides an empirical evidence on the response of sorghum production to output and input prices as well as to public investments. The study used data spanning the period 1978 to 2014 to fit an autoregressive distributed lag (ARDL) specification of the output response equation using the EViews statistical software. The findings show that sorghum production in Kenya does not respond to increases in its output price and is not adversely affected by input prices. Increased development spending in agriculture lead to increased sorghum production and also increase use of fertilisers and certified seeds. The findings suggest that policy interventions based on output prices and input prices alone would not yield the desired increased expansion in sorghum production. The government should increase budgetary allocations to agricultural development.
\end{abstract}

Keywords: food security, input prices, output prices, production response, public investments, sorghum

\section{Introduction}

Achievement of food security remains central in agricultural development agenda for Kenya in line with national, regional and global development agreements. The aim is to prevent the undesirable consequences of insufficient nutrition including predisposing individuals to diseases with losses in labour productivity, poor cognitive development in young children and their adverse effects on economic growth (Republic of Kenya, 2005; Kibaara et al., 2008; FAO, 2004). Towards realisation of food security in the country increased production of food crops is emphasised because majority of the country's households rely on own production of food and the growing urban consumers rely on surpluses from rural household production for their nutritional requirements. Self-sufficiency in most food products is also desired so that the scarce foreign exchange is secured for importing capital for industrialisation (Republic of Kenya, 1974; 1981). Among the food crops cultivated in Kenya, cereals which include, maize, wheat, rice, sorghum and millet, constitute the larger proportions of diets of most households and as such, their supply is central to the country's food security (Republic of Kenya, 2009).

Sorghum is the second cereal food crop after maize grown by a majority of the households involved in food crops production. Sorghum is highly tolerant to drought and able to withstand periods of water-logging because of its extensive root system, waxy bloom on leaves that reduces water loss, ability to stop growth in periods of drought and resume it when the stress is relieved (Muui, Muasya and Kirubi; 2013). The crop's Rainfall requirement is in the range of $420 \mathrm{~mm}-630 \mathrm{~mm}$ per annum for good growth and production. Given that 80 per cent of land area in Kenya is classified as arid and semi-arid lands characterised by low rainfall, sorghum is one of the crops that can help many households to be food secure. It can serve as an alternative to maize which cannot give a good crop in the arid and semi-arid areas and with low or inadequate rainfall. Sorghum is closely related to maize in utilization. The flour from its grains are used in making porridge and ugali just as in maize flour. Other innovative uses such as in making pastries, cakes and pilau when mixed with legumes and other cereals is also becoming common. Further, the crop has a high nutritional value. The grain has high levels of iron 
and zinc, hence may be used to reduce micronutrient malnutrition (Kang'ethe, 2004; Export Processing Zone Authority, 2005; Republic of Kenya, 2008; Muui, et al., 2013).

In Kenya, sorghum is mainly cultivated in Nyanza, Eastern, Western and Rift Valley provinces (Republic of Kenya, 2003) by small scale producers under traditional farming systems over the years (Iren, 2004). It is one of the traditional crops that were orphaned in the early years of independence when public policy singled out maize as the main staple food so that budgetary support in production and through government controlled marketing boards favoured maize. Other policies focussing on producer prices, inputs subsidies, credit, research and extension activities, and resettlement programmes increased smallholder maize production in the 1960s and early 1970s. The situation lead to a change in eating habits and consequently was reduced production and consumption of the traditional cereals (mainly sorghum and millet) as people shifted to consumption of maize (Nyangito and Kimenye, 1995; Njuguna and Wasunna; 1995; Nyangito and Okello, 1998; Kang'ethe, 2004). However, from the late 1970s, rapid population growth and shortage of unexploited arable land in the high and medium potential areas prevented any marked improvement in food production and per capita nutritional intake and as a result some sections of the population remained food insecure (Republic of Kenya, 1981).

The critical role of expanding sorghum production for food security came into public policy limelight in 1981 through the first comprehensive national food policy (Republic of Kenya, 1981). The national food policy emphasised increased cultivation of sorghum especially in the arid and semiarid areas as a means of increasing the domestic supply of cereals in the country towards sustainable food security. Towards this end, the government proposed introduction of guaranteed minimum prices as incentives for expanding production. There has also been a focus on sorghum in agricultural research where the Kenya Agricultural Research Institute (KARI) has produced high yielding, pest and disease resistant sorghum varieties and promoted use of improved husbandry practices. The non-palatability problem of the bitter sorghum varieties that hindered its consumption have also been dealt with. The subsequent policies including the national nutrition policy have also emphasised increased consumption of the traditional cereals (Republic of Kenya, 2004; 2009)

Although expansion of sorghum production remains critical for food security in Kenya and continues to be a focus of public policy, most empirical studies in the food crops subsector in Kenya have focused more attention on maize where there is extensive literature on the response of production to both price and non-price factors (Onono, Wawire and Ombuki, 2013, Onono, 2012; Mbithi, 2000; Mose, Burger and Kuvyenhoven, 2007; Olwande, Ngigi, and Nguyo, 2009). An analysis of sorghum production behaviour and how it relates to its output price, output price of other food crops, input prices and public investments in Kenya would be important to provide knowledge on the relative importance of the various policy instruments. This study provides an empirical evidence on the influence of output and input prices as well as public investments on sorghum production in the Kenya.

\section{Methodology}

\subsection{Research Design}

This study adopted a quantitative design. Quantitative data on aggregate output of each crop, output and input prices, public investment in agriculture, roads construction and maintenance, and macroeconomic variables were compiled from published sources in the period spanning the years 1978 to 2014 from various sources including Food and Agricultural Organisation (FAO) production statistics (FAO, 2011), Economic surveys and statistical abstracts (various issues) from the National Bureau of Statistics of the Republic of Kenya and the International Financial Statistics (CD-ROM). Quantitative techniques were used to analyse the data.

\subsection{Theoretical Framework}

This study applied the theoretical model of utility maximising farmers developed by Singh, Squire, and Strauss (1986) in which a crop producing household is conceptualised as both a producer and consumer of its product. The crop producer sells surpluses of output over consumption to the market to acquire incomes to purchase other consumption goods. As typical in subsistence agriculture, the household allocates part of the family labour to the farm production activities and some of the time to off farm activities and leisure. The assumptions of the model that the farmer pursues utility maximisation through the consumption of a basket comprising home produced goods, market purchased goods, and leisure, subject to full income constraint is therefore applicable and the household's decision problem can thus be presented as: 


$$
\operatorname{Max} U=U\left(X_{a}, X_{m}, X_{l}\right)
$$

Subject to

$$
\begin{gathered}
P_{m} X_{m}=P_{a}\left(Q_{a}-X_{a}\right)-P_{l}(L-F)-P_{v} V+E: \text { cash income constraint } \\
X_{1}+F=T: \text { Time conatraint } \\
Q_{a}=Q(L, V, A, K): \text { Pr oduction constraint }
\end{gathered}
$$

where; $X_{a}, X_{m}$ and $X_{l}$ represent an agricultural staple, a market purchased good and leisure, respectively. $P_{a}, P_{m}$, $P_{l}$ and $P_{v}$ are the market prices for the agricultural staple, market purchased commodity, the market wage and price of a variable input such as fertiliser, respectively; $Q_{a}$ is the household's production of the staple so that $Q_{a}-$ $X_{a}$ is the marketed surplus; $L$ is total labour input and $\mathrm{F}$ is family labour input; $V$ is a variable input such as fertiliser; $E$ is any non-labour or non-farm income; $T$ is total stock of household time; A and $\mathrm{K}$ are fixed quantities of land and capital inputs. The solutions to the first order conditions of the farm household utility maximisation problem give the optimal input demands and output supply functions as dependent on output and input prices, technological parameters of the production function, and the fixed factors. In the case where the farmer produces more than one crop, the derived output supply function are functions of producer prices for all crops cultivated and prices of variable inputs including the market wage rate. The specification of output supply function for a given crop for a farm producing $n$ different crops with $m$ different variable inputs therefore becomes:

$$
Q_{i}=f\left(P_{1, \ldots, n} ; P_{v(1, \ldots, m)} ; A_{1, \ldots k)}\right)
$$

Public investments can be introduced in the output supply function in equation 5 by considering the fact that farmers face transaction costs when selling their output and when obtaining purchased inputs (Key, Sadoulet and de Janvry, 2000). Such transaction costs have the effect of reducing prices received while increasing prices paid by farmers. The transaction costs are thought to reduce with knowledge of the markets (such as those from agricultural research and extension services), improvements in transport and communications infrastructure and macroeconomic conditions as well as institutional factors (Onono, et al., 2013). Public investments by the government on construction of roads, transport and communication, agricultural development services (research and extension services), institutional reforms and macroeconomic stability are therefore important. The basic output supply functions can then be modelled to incorporate these factors alongside the output and input prices in models of crop production. The argument in previous studies for non-price incentives for crop production was that they would complement prices in raising food production in Kenya (Bond, 1983; Nyangito and Okello, 1998; Mbithi, 2000; Mose et aI., 2007; Olwande et al., 2009). The implication is that they would set an environment that make prices more effective in influencing production and hence increased food supply in the country. This position could be analysed through inclusion of interaction terms between the variables capturing public investments and macroeconomic stability with output and input prices (Onono et al., 2013)

Contrary to the standard theory of the firm which stipulates instantaneous responses of outputs to inputs and therefore to prices so that supply in a given period is influenced by current prices, agricultural production is characterized by biological lags between input application and output production. The technical rules implied by the production function of an agricultural firm may also change during the course of the production process if technological and institutional factors prevent intended production decisions from being fully realised in one time period (Timmer, Falcon and Pearson, 1983) hence the actual change in production may only be a fraction of the desired change during a given time period (Madala, 2001). The partial adjustments are due to minimisation of total costs of adjustment and those associated with being in disequilibrium.

Further, when farmers go to plant, they do not know exactly at what price they will sell the output. Their decisions are based on what they expect prices to be at the time of sale of produce. How farmers form expectations is therefore important in the analysis of agricultural production behaviour. Expectations formation in agriculture is assumed to follow an adaptive scheme (Nerlove, 1958; Bond, 1983; Kwanashie, Ajilima and Garba., 1998; McKay, Morrissey and Vaillant, 1998; Madala, 2001; Muchapondwa, 2008) so that agents revise their expectations downwards or upwards based on the most recent forecast error. The entire past values are 
therefore considered but with declining weights for values farther in the past. Adaptive expectations and partial adjustments in agricultural supply dynamics can be captured by use of autoregressive distributed lag (ARDL) specification (Madala, 2001).

\subsection{The Empirical Model}

Following the theoretical argument, output of sorghum $(Y)$ was modelled as dependent on its output price $\left(P_{s}\right)$, output price of maize $\left(P_{m}\right)$ which is a related cereal food crop in most regions where sorghum is grown, price of fertiliser $\left(V_{f}\right)$, and price of certified (improved) sorghum seeds $\left(V_{\mathrm{s}}\right)$, agricultural wage $(\mathrm{W})$ and public investment expenditures on road construction and maintenance and the improvement of transport and communication $\left(\mathrm{G}_{\mathrm{R}}\right)$; agricultural development $\left(\mathrm{G}_{\mathrm{A}}\right)$, and macroeconomic stability captured by per capita GDP; lending rate (R) and inflation rate (INL). Dummy variables $\left(D_{i}\right)$ were used to capture the effects of institutional changes, weather conditions and other unique occurrences that would have affected production of the crop. The model was specified in ARDL form as in equation 6.

$$
Y_{t}=f\left(Y_{t-i}, P_{s(t-i)}, P_{m(t-i)}, V_{f(1-i)}, V_{s(t-i)}, W_{t}, D_{i}, G R_{t-i}, G A_{t-i}, G D P_{t-i}, R_{t-i}, I N L_{t-i}\right)
$$

\subsection{Model Estimation}

Before estimation of the model stationarity tests were conducted on the time series in order to guard against spurious results. The Augmented Dickey Fuller (ADF) and Phillips Perron (PP) tests were used. Correlation analysis was also conducted to ascertain absence of high correlation between the independent variables. All variables in the model except for the dummies were in their log values so that the estimated coefficients directly measure elasticity values. The EViews statistical software (version 5) was used.

In construction of the ARDL models, lagged values of both dependent and independent variables were included only if doing so improved the adjusted R-squared and minimised the information criteria values. Interaction terms between output and input prices were also added following a similar argument. The response equation was estimated by least squares method. Diagnostic tests including the residual based tests, model specification and stability tests were undertaken to ensure that the estimated model was appropriate for consistent coefficient estimates.

The response equation obtained was transformed into the distributed lag form in order to define long run relationships which was then used to distinguish between short run and long run responses. The short run elasticity estimate was computed based on the coefficients of non-lagged explanatory variable, while long run elasticity estimate was computed based on the sum of coefficients of the respective independent variable following procedures in Christiaan, de Boer, Frances, Kloek, van Dijk (2004).

\section{Results}

\subsection{Time Series Property Tests Results}

The study conducted unit root tests on all the time series and multicollinearity tests between series used as independent variables. The unit root tests results for all the time series used in the study are presented in table 1 . In the ADF and PP tests for presence of unit root in time series, the null hypothesis for unit root is rejected when the test statistic is greater than the critical value at the desired level of significance otherwise the null hypothesis is not rejected. 
Table 1. Unit root tests results based on ADF and PP tests

\begin{tabular}{|c|c|c|c|c|c|}
\hline Variable & $\begin{array}{l}\text { Type of } \\
\text { Test }\end{array}$ & Form of test & $\begin{array}{l}\text { Computed } \\
\text { Test Statistic }\end{array}$ & $\begin{array}{l}\text { Critical Value } \\
\text { at } 5 \%\end{array}$ & Conclusion \\
\hline Log sorghum & ADF & C-level & -2.6376 & -2.9472 & Non stationary \\
\hline \multirow[t]{2}{*}{ Output } & & C\&T-level & -2.5459 & -3.5426 & \\
\hline & PP & C-level & -3.7351 & -2.9446 & Stationary \\
\hline Log maize & ADF & C-level & -0.7988 & -2.9472 & Non stationary \\
\hline \multirow[t]{3}{*}{ Price } & & C\&T-level & -2.5455 & -3.5426 & \\
\hline & $\mathrm{PP}$ & C-level & -0.5644 & -2.9446 & \\
\hline & $\mathrm{ADF}$ & $1^{\text {st }}$ diff. & -5.3816 & -2.9499 & $\mathrm{I}(1)$ \\
\hline Log sorghum & $\mathrm{ADF}$ & C-level & -2.9613 & -2.9472 & Stationary \\
\hline Price & & C\&T-level & -4.0898 & -3.5426 & \\
\hline Log fertiliser & $\mathrm{ADF}$ & C-level & -0.6086 & -2.9472 & Stationary \\
\hline Price & & C\&T-level & -5.0485 & -3.5426 & \\
\hline Log seed & $\mathrm{ADF}$ & C-level & -0.7007 & -2.9472 & Non stationary \\
\hline \multirow[t]{3}{*}{ Price } & & C\&T-level & -1.5973 & -3.5426 & \\
\hline & PP & C-level & -0.6237 & -2.9446 & \\
\hline & $\mathrm{ADF}$ & $1^{\text {st }}$ diff. & -4.4941 & -2.9499 & $\mathrm{I}(1)$ \\
\hline \multirow{4}{*}{$\begin{array}{l}\text { Log agricultural } \\
\text { Wage }\end{array}$} & $\mathrm{ADF}$ & C-level & -1.2191 & -2.9472 & Non stationary \\
\hline & & C\&T-level & -1.7098 & -3.5426 & \\
\hline & PP & C-level & -1.1214 & -2.9446 & \\
\hline & $\mathrm{ADF}$ & $1^{\text {st }}$ diff. & -3.5560 & -2.9499 & $\mathrm{I}(1)$ \\
\hline \multirow{4}{*}{$\begin{array}{l}\text { Log development } \\
\text { expenditure in } \\
\text { agriculture }\end{array}$} & $\mathrm{ADF}$ & C-level & -1.5078 & -2.9472 & Non stationary \\
\hline & & C\&T-level & -2.2325 & -3.5426 & \\
\hline & PP & C-level & -1.4026 & -2.9446 & \\
\hline & $\mathrm{ADF}$ & $1^{\text {st }}$ diff. & -4.4811 & -2.9499 & $\mathrm{I}(1)$ \\
\hline \multirow{4}{*}{$\begin{array}{l}\text { Log development } \\
\text { expenditure on } \\
\text { roads, transport and } \\
\text { communication }\end{array}$} & $\mathrm{ADF}$ & C-level & -1.7992 & -2.9472 & Non stationary \\
\hline & & C\&T-level & -0.9858 & -3.5426 & \\
\hline & PP & C-level & -1.8969 & -2.9446 & \\
\hline & $\mathrm{ADF}$ & $1^{\text {st }}$ diff. & -4.2781 & -2.9499 & $\mathrm{I}(1)$ \\
\hline \multirow{4}{*}{$\begin{array}{l}\text { Log real per capita } \\
\text { GDP }\end{array}$} & $\mathrm{ADF}$ & C-level & -1.7023 & -2.9472 & Non stationary \\
\hline & & C\&T-level & -1.9759 & -3.5426 & \\
\hline & $\mathrm{PP}$ & C-level & -1.5445 & -2.9446 & \\
\hline & $\mathrm{ADF}$ & $1^{\text {st }}$ diff. & -3.6229 & -2.9499 & $\mathrm{I}(1)$ \\
\hline Log lending rate & $\mathrm{ADF}$ & C-level & -4.8482 & -2.9472 & Stationary \\
\hline Log inflation rate & $\mathrm{ADF}$ & C-level & -3.9659 & -2.9472 & Stationary \\
\hline
\end{tabular}

The results in table 1 show that the series for log sorghum output, log sorghum price, log fertiliser price, $\log$ inflation rate and log lending rate are stationary. On the other hand, log maize price, log agricultural wage, log seed price, log of development expenditure in agriculture, log development expenditure on roads, transport and communication, and log per capita GDP are non-stationary because the null hypothesis for the presence of unit root in the series could not be rejected. However, in all the cases for non-stationary series, the first differences were stationary hence are integrated of order one (1).

Given that the variables to be included in the specified models were integrated of different orders the ARDL specifications that is capable of estimating long run relationship in such a situation was further justified. After estimation of the ARDL, true cointegration was ascertained upon establishment of the model's stability condition. The ARDL's stability condition is based on the stationarity condition of the characteristic equations from the autoregressive component of the models. In the estimated output response equation for this study the sum of the coefficients of lagged values of the dependent variable was less than one (see table 2) and the absolute value of the individual coefficients were less than one thus confirming stability and therefore true cointegration

The test for high collinearity between the independent variables was based on partial correlation coefficients between the variables as suggested by Farrar and Glauber (1967). The results indicated that the log of sorghum price, log of agricultural wage, log of development expenditure on roads, transport and communication, log 
inflation rate, were not highly correlated to any other variable. The remaining variables; log of maize price, $\log$ of fertiliser price, log seed price, log of development expenditure in agriculture, log real per capita GDP and log lending rate had absolute correlation coefficients greater than 0.8 with some other variables. However, when a regression was done with all the regressors, the output did not reveal a problem of near singular matrix. Further, there were many significant t- ratios accompanying the high values of adjusted R-squared indicating that multicollinearity was not a serious problem in the estimated model. Having satisfied the basic time series properties for use of least squared approach, the sorghum output response equation was estimated. The estimated response equation is as specified in table 2

Table 2. Estimated Sorghum Output Response Equation

\begin{tabular}{|c|c|c|c|}
\hline \multicolumn{4}{|l|}{ Dependent Variable: Log Sorghum Output } \\
\hline Independent Variable & Coefficient & t-Statistic & Prob. \\
\hline Constant & 1.1599 & 0.5453 & 0.6004 \\
\hline First lag of log sorghum output & $-0.4655 * * *$ & -17.00 & 0.0000 \\
\hline Log sorghum price & $-0.7882 * * *$ & -5.510 & 0.0006 \\
\hline First lag of log sorghum price & -0.0257 & -0.136 & 0.8954 \\
\hline Log maize price & $-0.6379 * * *$ & -6.299 & 0.0002 \\
\hline First lag of log maize price & -0.1052 & -1.607 & 0.1468 \\
\hline Second lag of Log maize price & $-1.0073 * * *$ & -11.22 & 0.0000 \\
\hline Log fertilizer price & $2.8721 * * *$ & 4.423 & 0.0022 \\
\hline Log seed price & -0.3075 & -0.536 & 0.6064 \\
\hline Log agricultural wage & $0.6014 * * *$ & 3.850 & 0.0049 \\
\hline Log development expenditure in agriculture & $1.2603 * * *$ & 3.798 & 0.0053 \\
\hline Log development expenditure on roads, transport and communication & $-0.1866 * * *$ & -5.393 & 0.0007 \\
\hline Log lending rate & 0.2781 & 1.588 & 0.1509 \\
\hline Log inflation rate & $-1.1775 * * *$ & -4.837 & 0.0013 \\
\hline Log per capita GDP & 0.4947 & 2.120 & 0.0668 \\
\hline Change in governance 1 & $0.3952 * * *$ & 3.421 & 0.0091 \\
\hline \multicolumn{4}{|l|}{$D_{1}=1$ for $1972-1978: 0$ otherwise } \\
\hline Change in governance 2 & 0.1689 & 1.494 & 0.1735 \\
\hline \multicolumn{4}{|l|}{$D_{2}=1$ for $1979-2002: 0$ otherwise } \\
\hline Market Liberalisation & 0.2128 & 1.385 & 0.2035 \\
\hline Log inflation rate $* \log$ fertilizer price & $0.1487 * * *$ & 3.835 & 0.0050 \\
\hline Log development exp. in agriculture $* \log$ fertilizer price & $-0.4619 * * *$ & -3.464 & 0.0085 \\
\hline Log development expenditure $* \log$ seed price & $0.2626 * *$ & 2.593 & 0.0320 \\
\hline Coup attempt of 1982: $\mathrm{D}=1$ and 0 otherwise & $-1.3915^{* * *}$ & -22.399 & 0.0000 \\
\hline Favourable weather $(1977,1989,2000)$ : & $0.3923 * * *$ & 11.376 & 0.0000 \\
\hline \multicolumn{4}{|l|}{$\mathrm{D}=1$ and 0 otherwise } \\
\hline $\begin{array}{l}\text { Lagged residual from Maize output equation } \\
\text { (shocks in maize production) }\end{array}$ & $4.7929 * * *$ & 3.9792 & 0.0041 \\
\hline Adjusted R-Squared & 0.992120 & & \\
\hline Standard error of Regression & $\mathbf{0 . 0 3 7 3 3 4}$ & & \\
\hline Durbin-Watson statistic & 2.646334 & & \\
\hline F-Statistic & 168.8693 & & \\
\hline Probability (F-Statistic) & 0.000000 & & \\
\hline
\end{tabular}

Asterisk $(* *)$ and $(* *)$ indicates that the effect is significant at $1 \%$ and $5 \%$, respectively

\subsection{Diagnostic Test Results}

Before the results in table 2 could be accepted for addressing the study's objectives the model was subjected to various diagnostic tests to ascertain statistical soundness. These included the residual based tests, specification tests and model stability tests. The results were as shown in table 3 
Table 3. Diagnostic tests results

\begin{tabular}{ll}
\hline Type of test & P-value of the test statistic \\
\hline Histogram-Normality Test (Jarque-Berra test) & 0.957494 \\
ARCH LM Test & 0.138714 \\
Breusch-Godfrey LM test for Serial Correlation & 0.571284 \\
Ramsey RESET test & 0.2660 \\
\hline
\end{tabular}

The higher p-value of the Jarque-Bera statistic which was greater than 0.05 showed that the normality assumption of the regression residuals could not be rejected at 5 per cent level of significance. It was thus concluded that regression residuals followed a normal distribution and as such results could be used in hypothesis tests as both the t-statistic and the F-statistic assume normal distribution. Since the model was estimated by including lagged values of the dependent variable, the Breusch-Godfrey (BG) langrage multiplier test for serial correlation which is capable of testing serial correlation in such models (Christiaan et al., 2004; Gujarati, 2004; Greene 2008) was used. The high probability value for the F- statistic for the BG tests, indicated that the null hypothesis of no serial correlation in the models could not be rejected which implied that there were no serial correlation problems in the regression residual series. Similarly in the LM test for no ARCH, the probability value of the F-statistics was greater than 0.05 indicating that the null hypothesis could not be rejected at 5 per cent level of significance. It was then concluded that the residual series did not exhibit problems of heteroscedasticity.

RESET test was conducted to ascertain that there was no alternative better specification for the equation as well as test for omitted variables, incorrect functional form, correlation between regressors and the error term, which may be as a result of measurement errors in regressors, simultaneity, or presence of lagged values of the dependent variables on the right hand side of the models. The probabiliy value for the F-statistic obtained was greater than 0.05 which ruled out the possibility of specification errors in the models. Recursive estimation was also performed in order to determine constancy or stability in parameters of the models using ever larger subsets of the sample data. Recursive residual tests, CUSUM tests, CUSUM residual squares tests, one-step-forecast tests, N-step-forecast tests and recursive coefficient tests were performed and for all the tests the residuals lie within the two standard error bands implying stability or constancy in the parameters.

The model was considered appropriate for addressing the research questions. The response of sorghum production to output prices, input prices and public investments were captured by elasticity estimates computed from the coefficients of each of the relevant variables by obtaining the distributed lag form of the response equation. For the independent variables where lagged values had significant coefficients, distinction between short run and long run elasticity estimates was made.

\section{Discussions}

\subsection{Response of Sorghum Production to Output Prices}

The study considered how sorghum production responds to its output price and that of maize which is an alternative food crop. The findings from table 2 report a negative and statistically significant coefficient of log sorghum price. As argued by Muchapondwa (2008) a negative coefficient for price in the current period in an output response equation for an agricultural crop indicates reverse causality between output prices and output supply, especially when weak exogeneity assumption of regressors do not hold. As such the negative coefficient in this case suggests that sorghum output price in a given period is negatively affected by increased output in the period. The coefficient of the first lag of log sorghum price was statistically insignificant indicating that sorghum output is not influenced by its output price. Due to biological lags in realising output changes following a price change, if prices influence output decisions, the coefficient of lag price would be expected to be statistically significant. The results in this case suggest that sorghum production in Kenya is not responsive to changes in its output price. Policies targeting prices may therefore not be effective in realising expected expanded production to increase supply of cereals for food security. The lack of response may also indicate that a good proportion of the crop cultivation in the study period was mainly for subsistence.

The results further show that sorghum production respond to maize output price. The coefficient of $\log$ maize price is negative and significant, suggesting that production of sorghum decreases as maize output price increases. In the small holder food crop production in Kenya the two crops; sorghum and maize are mainly grown for subsistence, some surpluses from the subsistence systems are sold for income which enables households to purchase market goods. The reduction in sorghum production when maize output price increases 
indicate that producers get attracted to the high profit prospects and allocate more resources away from sorghum production to expand maize production. More so maize is the main staple food for a majority of Kenyan households, both in rural and urban areas and any surpluses in its production finds ready market, unlike for sorghum where consumption is confined more to its producers. The finding indicates that in the food production subsector, production resources can shift across different crops contrary to the modelling adopted in earlier studies that implied resource shifts to occur only between food crops and cash crops as in McKay et al. (1999) on aggregate agricultural supply response in Tanzania, and in Mbithi (2000) in a study on maize production response to prices in Kenya.

\subsection{Response of Sorghum Production to Input Prices}

The study considered three inputs in the food crop production system which included labour, fertilisers and purchased seeds. Most households depend on family labour to carry out most of the cultivation activities in small holder systems. However, with expanded production and seasonality of most of the activities, farmers often supplement family labour with hired labour. In this way, the average wage paid to hired labour becomes an important cost on the producer and may limit output or the extent to which production can be expanded. Further, crops production may be affected if households hire out their labour resources in off-farm productive activities especially when the marginal productivity in such activities is higher than that from the farm. Use of fertilisers and certified seeds are encouraged in sorghum production for a good crop because of declining productivity of land resulting from continuous cropping, land degradation, soil erosion, effects of crop pests and diseases (Republic of Kenya, 1981; 1997; 2004; 2008). Response of sorghum to the input's prices was investigated to aid in assessing the extent to which policies addressing input price constraints would increase production of the crop.

The coefficient of the log agricultural wage is positive and statistically significant showing that over time, sorghum production increase as the average agricultural wage increases. The positive response to agricultural wage is contrary to the standard theory of the firm, which postulates that output supply function is non-increasing in input prices (Varian, 1992). However, agricultural wage may not be strictly exogenous. The seasonal nature of agricultural production means that critical activities should be carried out at particular time periods (Timmer et al., 1983). This distinguishes peak agricultural periods from the other periods especially where agriculture is mainly dependent on rain fed conditions. Expansion of agricultural production raises demand for labour during the peak periods, which consequently raises wages. If wages rise because of such increases in demand for labour, then it can be construed that increased use of hired labour to complement family labour enables producers to realise increased output from their expanded activities. This can explain the positive relationship between outputs and agricultural wage for sorghum. The computed wage elasticity from the coefficient was 0.4103 indicating an inelastic response which can be attributed to the large subsistence production of sorghum dominated by use of family labour.

The coefficient of log fertiliser price is positive and statistically significant indicating that production of sorghum increases with increase in average fertiliser price. Unlike in maize production that requires heavy intake of nitrogen and phosphorus for a good crop so that continuous cropping must be accompanied with replenishment through application of fertilisers, sorghum crop grows well with low fertiliser use (Iren, 2004). Increase in average prices for fertilisers which would lead to low use of fertilisers in food crops subsistence farming would therefore greatly affect yields in maize. The positive response of sorghum output following a rise in average fertiliser prices could be a sign that producers revert to more sorghum production when fertiliser use in maize reduces and cannot guarantee good crop following an increase in the input's prices. Such a shift can be interpreted as a cautious behaviour by producers to avoid the risk of plunging their households into inadequate nutrition by increasing production of food crops where prospects are more certain (Mendola, 2007)

The coefficients for the interaction term between log inflation and log fertiliser price was positive and statistically significant indicating that with rising inflation, sorghum production response to increase in average fertiliser price increases and is more compared to a case of low inflation. Inflation raises the cost of living leading to low savings as such those farmers relying on own savings to purchase fertilisers for use in maize production would be unable to do so. Increase in sorghum production following growing inflation over time could therefore be construed as a means to guarantee their nutritional security. On the contrary, the coefficient of the interaction term between $\log$ agricultural development expenditure and $\log$ fertiliser price is negative and statistically significant. It is not clear why this would be the case but a plausible explanation could be attributable to the fact that part of the expenditures on agricultural development is sometimes used to subsidise fertiliser prices. However, such an argument can only be sustained if distribution of agricultural development expenditure across different votes would be available and is therefore out of the scope of this study which used aggregate expenditures. 
In the case of average prices of purchased seed, the coefficient of log seed price was found to be statistically insignificant. The finding indicates that production of the crop is insensitive to changes in average price of purchased seed which suggests that in the study period sorghum producers may not have relied heavily on use of certified seeds. Majority of the small holders who cultivate the crop do not use of certified seeds but often rely on seeds selected and prepared from own production which could explain the lack of any significant response of output to seed prices (Republic of Kenya, 2009). On the contrary the coefficient for the interaction term between $\log$ development expenditure in agriculture and $\log$ seed price, are positive and statistically significant suggesting that increased allocation of resources to agricultural development raises response to purchased seed prices. This can be explained as resulting from the ministry of agriculture being able to allocate more resources to expand its research and extension activities, which sometimes entail demonstrations to expose farmers to the advantages of adopting improved methods of production, including use of certified seeds. The results signal an increased use of certified seeds with increased provision for development spending in agriculture and that yield effects of use of purchased seed could exceed the cost effect of rising seed prices.

\subsection{Response of Sorghum Production to Public Investment}

Kenya's national food policy specifies various public policy avenues for increased food production that do not directly depend on output or input prices. These include, enhanced research and extension, processing and marketing, access to credit and infrastructure development (Republic of Kenya, 1981; 2004; 2009; Nyangito and Kimenye, 1995). The realisation of these are through allocation of resources for agricultural development, infrastructural development and the establishment and management of parastatals which are directly involved in marketing of commodities. The study thus analysed the response of sorghum output to public expenditures on agricultural development and for investments to improve infrastructure for transport and communication.

The results show a positive and statistically significant response of sorghum output to agricultural development expenditure while response to development expenditures on roads, transport and communication is negative. The findings therefore suggest that production of sorghum increases with increased spending by the central government on agricultural development. The computed elasticity estimate is 0.86 showing that over time, an increase in agricultural development expenditure by 10 per cent would raise sorghum output by 8.6 per cent which is an inelastic response.

The negative and statistically significant response of sorghum to increased expenditures on road, transport and communication could be as a result of resources leaving sorghum production towards commercial economic activities that would effectively utilise the improved infrastructure. The computed elasticity estimate indicates that a 10 per cent increase in resource allocations towards infrastructural development in Kenya would reduce sorghum production by 1.2 per cent, all other factors held constant which is an inelastic response. Moreover, expenditures by the central government for such infrastructure development are usually mainly used in improving highways connecting major urban centres and not rural infrastructure.

\section{Conclusions}

This study was conducted to ascertain the response of sorghum production in Kenya to output prices, input prices and public investments. From the findings it is concluded that sorghum production in Kenya does not respond to increases in its output price but responds positively to increases in maize output prices indicating cross output price effects and substitutability of the two food cereals in production just as in consumption. With regard to the three inputs considered in the study, sorghum production is indicated to increase with increase in fertiliser prices, and agricultural wages but it is not responsive to increase in prices of purchased seed. The results therefore imply that increase in the input prices do not confer any adverse effects on the production of the crop. The study therefore provide an empirical evidence that policy interventions on the crops output price as well as input prices on their own would not yield the desired increased expansion in sorghum production in Kenya to address the food security and self-sufficiency concerns.

Production of the crop increases with increased expenditures on agricultural development. Further increased expenditure on agricultural development also increases use of fertilisers and improved seeds in crops even with rising prices. The findings therefore provide evidence that increased development expenditures in agriculture is required to enhance use of high yielding inputs for increased supply of food in the country which in turn would ensure food security. Towards raising the extent of responsiveness of production to such spending which was found to be inelastic, the Ministry of Agriculture should ensure that the services offered to small scale producers from the development expenditures are effective and adequate to enable increased use of improved farming technologies. More of such resources should be spent on activities that will ensure that outputs from research are effectively transferred for farmers' consumption and to ensure that information on improved practices is reaching 
the farmers with any uncertainties in the use of such practices removed through continued provision of extension services.

\section{References}

Bond, M. E. (1983). Agricultural responses in sub-Saharan African countries, International Monetary Fund Staff papers, 30(4), 703-726.

Breusch, T. S. (1978). Testing for autocorrelation in dynamic linear models, Australian Economic Papers, 17, 334-355. https://doi.org/10.1111/j.1467-8454.1978.tb00635.x

Christiaan, H., de Boer, P., Frances, P. H., Kloek, T., \& van Dijk, H. K. (2004). Econometric methods with applications in business and economics, Oxford: Oxford University Press.

Dickey, D. A., \& Fuller, W. A. (1976). Distribution of the estimators for autoregressive time series with a unit root, Journal of the American Statistical Association, 74, 427-431.

Export Processing Zone Authority. (2005). Grain production in Kenya, Nairobi, Export Processing Zone Authority

Farrar, D. E., \& Glauber, R. R. (1967). Multicollinearity in regression analysis; the problem revisited, Review of Economics and statistics, 49, 92-107. https://doi.org/10.2307/1937887

Food and Agricultural Organization. (2011). Production statistics, Rome: Food and Agriculture Organisation

Godfrey, L. G. (1978). Testing against general autoregressive and moving average error models when the regressor include lagged dependent variables, Econometrica, 46, 1293-1302. https://doi.org/10.2307/1913829

Greene, W. (2008). Econometric analysis, $6^{\text {th }}$ ed. New Jersey: Pearson-Prentice Hall

Gujarati, D. N. (2004). Basic econometrics, $4^{\text {th }}$ ed. New York: McGraw Hill Companies

Iren, L. (2004). Sorghum and millets: in cultivated plants, primarily as food sources; in Fuleky, G (ed.) Encyclopedia of Life Support Systems developed under the Auspices of the UNESCO. Oxford: EOLSS Publishers. http://citeseerx.ist.psu.edu/viewdoc/download/doi/10.1.1.624.6032

Kang'ethe, W. G. (2004). Agricultural development and food security in Kenya: A case for more support. A paper prepared for agriculture and food organisation (September)

Key, N., Sadoulet, E., \& de Janvry, A. (2000). Transaction costs and agricultural household supply response. American Journal of Agricultural Economics, 82(2), 245-259. https://doi.org/10.1111/0002-9092.00022

Kibaara, B., Gitau, R., Kimenju, S., Nyoro, J., Bruntrup, M., \& Zimmermann, R. (2009). Agricultural policy-making in sub-Saharan Africa; CAADP progress in Kenya, Nairobi: Tegemeo Institute of Agricultural Policy and Development

Kwanashie, M., Ajilima, I., \& Garba, A. (1998). The Nigerian economy: Response of agriculture to adjustment policies. Nairobi: Africa Economic Research Consortium research paper No. 78 (March)

Madala, G. S. (2001). Introduction to econometrics, $3^{\text {rd }}$ ed. Delhi: Wiley \& Sons

Mbithi, L. M. (2000). Agricultural policy and maize production in Kenya: PhD Thesis, Universiteit Gent

McKay, A., Morrissey, O., \& Vaillant, C. (1998). Aggregate export and food crop supply response in Tanzanian. A discussion paper in the CREDIT project on infrastructural and institutional constraints to export promotion. Centre for Research in Economic Development and International Trade: Research Paper No. 98/4.

Medola, M. (2007). Farm household production theories: a review of institutional and behavioural responses, Asian Development Review, 24(1), 49-64.

http://citeseerx.ist.psu.edu/viewdoc/download/doi/10.1.1.130.5733

Mose, L. O., Burger, K., \& Kuvyenhoven, A. (2007). Aggregate supply response to price incentives: The case of smallholder maize production in Kenya. Africa crop science conference proceedings in Egypt: Africa Crop Science Society, 8, 1271-1275.

Muchapondwa, E. (2008). Estimation of the aggregate agricultural supply response in Zimbabwe: The ARDL approach to cointegration. University of Cape Town, School of Economics: Working paper Number 90. http://citeseerx.ist.psu.edu/viewdoc/download/doi=10.1.1.528.56

Muui, C. W., Muasya, R. M., \& Kirubi, D. T. (2013). Baseline Survey on factors affecting Sorghum production 
and use in Eastern Kenya. African Journal of Food, Agriculture, nutrition and Development, 13(1).

Njunguna, N., \& Owino, W. (ed.) (1995). Towards indigenising the policy debate: From sessional paper no. 10 to structural adjustments. Nairobi: Institute of Policy Analysis and Research

Nyangito, H., \& Kimenye, L. (1995). Agricultural development policies in Kenya: 1963-1995 in Njunguna, N and W. Owino (ed.) Towards Indigenising the policy debate: From sessional paper no. 10 to structural adjustments. Nairobi: Institute of Policy Analysis and Research

Nyangito, H., \& Okello, J. (1998). Kenya's agricultural policy and sector performance: 1964 - 1996. Occasional Paper No. 04 1998, Nairobi: Institute of Public Policy and Research

Olwande, J., Ngigi, M., \& Nguyo, W. (2009). Supply responsiveness of maize farmers in Kenya: a farm-level analysis. Paper prepared for presentation at the international association of agricultural economists' conference, Beijing, China, (16-22 August)

Onono, P. A. (2012). food crops production response to economic incentives: a case of selected crops in Kenya. $\mathrm{PhD}$ Thesis, Kenyatta University

Onono, P. A., Wawire, N. W. H., \& Ombuki, C. (2013), The response of maize production in Kenya to economic incentives, International Journal of Development and Sustainability, 2(2) 530-543.

Republic of Kenya. (1974). National development plan for the period 1974-1978. Nairobi: Government Printer

Republic of Kenya. (1981). Sessional paper No. 4 of 1981 on national food policy. Nairobi: Government Printer

Republic of Kenya. (1997). National development plan for the period 1997-2001. Nairobi: Government Printer

Republic of Kenya. (2003). Economic survey. Nairobi: Government Printer

Republic of Kenya. (2004). Strategy for revitalising agriculture. Nairobi: Government Printer

Republic of Kenya. (2005). Millennium development goals status in Kenya: Progress report on millennium development goals. Nairobi: Government Printer.

Republic of Kenya. (2008). The first medium term framework: Kenya Vision 2030. Nairobi: Government Printer.

Republic of Kenya. (2009). Agricultural sector development strategy. Nairobi: Government Printer

Singh, I., Squire, L., \& Strauss, J. (eds.). (1986). Agricultural household models:Extensions and applications. Baltimore: Johns Hopkins University Press.

Timmer, C. P., Falcon, W. P., \& Pearson, S. R. (1983). Food policy analysis. Baltimore: John Hopkins University Press.

Varian, H. (1992). Microeconomic analysis. $3^{\text {rd }}$ ed. NewYork: W.W Norton \& Company Inc

\section{Copyrights}

Copyright for this article is retained by the author(s), with first publication rights granted to the journal.

This is an open-access article distributed under the terms and conditions of the Creative Commons Attribution license (http://creativecommons.org/licenses/by/3.0/). 